\title{
TAWAZUN
}

JURNAL PENDIDIKAN ISLAM

http://ejournal.uika-bogor.ac.id/index.php/TAWAZUN

Vol. 12, No. 1, Juni 2019, e-ISSN: 2654-5845, hIm. 128-150

DOI: 10.32832/tawazun.v12i1.1905

\section{StUdi KRITIS Konsep PENDIDIKaN BERbasis PlURALISME DI MAARIF INSTITUTE}

\author{
Ismail Syakban \\ Universitas Muhammadiyah Sumatra Barat, Indonesia \\ ismail.syakban@gmail.com
}

\begin{abstract}
This study focus on the problem of the pluralism concept based education by Maarif Institute in the Islamic perspective. The critical study will focus on three terms, namely: Foundations of Islamic Education, the Objectives of Islamic Education and its curriculum. The approach used in this study is the Descriptive Qualitative approach (QualitativeDescriptive Research and Content Analitic-Kritic), which is include in a critical study by describing and analyzing the Maarif Institute's thought related to the concept of pluralism based education. Materials and data obtained by studying books and journals published by the Maarif Institute, literatures related, so we get a picture of (description), thoughts, ideas, and insight to the object under study as well as a critical study of the research object. The results of this study indicates that the concept of pluralism based education by the Maarif Institute realized with three terms, which teaches the values of tolerance, non-violence values and values of inclusiveness. The concept of pluralism based education by the Maarif Institute has weaknesses and hidden dangers that can affect destroying religion and its teachings. Through the concept of pluralism based education will also let the doctrine from liberal secular to scrape out the power of Aqeedah of the Muslims.
\end{abstract}

Keywords: education; pluralism; Maarif Institute

\section{ABSTRAK}

Fokus masalah dalam penelitian ini adalah studi kritis terhadap konsep pendidikan berbasis pluralisme oleh Maarif Institute dalam perspektif Islam. Studi kritis tersebut akan difokuskan pada tiga term, yaitu: Landasan Pendidikan Islam, Tujuan Pendidikan Islam dan Kurikulum Pendidikan Islam. Pendekatan yang digunakan pada penelitian ini adalah pendekatan Qualitative-Descriptive Research and Content Analitic-Kritic (Penelitian Kualitatif-Deskriptif dan Analisis Konteks-Kritis), yaitu studi kritis dengan mendeskripsikan dan menganalisis pemikiran Maarif Institute terkait konsep pendidikan berbasis pluralisme. Bahan dan data didapatkan dengan menelaah buku dan jurnal terbitan Maarif Institute, literatur-literatur yang terkait, sehingga didapatkan gambaran (deskripsi), pemikiran, ide, dan penjelasan terhadap objek yang diteliti serta melakukan studi kritis terhadap objek penelitian tersebut. Hasil penelitian ini menunjukkan bahwa 
konsep pendidikan berbasis pluralisme oleh Maarif Institute direalisasikan dengan tiga term, yaitu mengajarkan nilai-nilai toleransi, nilai-nilai anti kekerasan dan nilai-nilai inklusifitas. Konsep pendidikan berbasis pluralisme oleh Maarif Institute memiliki kelemahan dan berdampak bahaya tersembunyi yang dapat menghancurkan agama dan ajarannya. Melalui konsep pendidikan berbasis pluralisme ini juga akan membukan pintu yang lebar bagi sekularisasi-liberal untuk mengikis habis kekuatan akidah kaum Muslimin.

Kata kunci: pendidikan; pluralisme; Maarif Institute

\section{Pendahuluan}

Di dunia pendidikan sekarang diduga sudah berkembang nilai-nilai pluralisme dan dikemas dalam konsep pendidikan berbasis pluralisme. Sebagai contoh adanya buku Pendidikan Multikultural Konsep dan Aplikasi (Ar-Ruzz Media: 2008) karya Ngainun Naim dan Achmad Sauqi, buku Pendidikan Karakter: Mengarusutamakan Nilai-nilai Toleransi Anti Kekerasan dan Inklusif (Maarif Institute: 2012) karya Dian Lestari.

Menurut Ngainun Naim dalam bukunya Pendidikan Multikultural Konsep dan Aplikasi, Konsep pendidikan berbasis pluralisme adalah konsep pendidikan yang berusaha melahirkan peserta didik yang memiliki cakrawala pandang luas, mengharga perbedaan, penuh toleransi, dan penghargaan terhadap segala bentuk perbedaan. Ngainun menuliskan bahwa:

"Pendidikan yang seragam dan tidak menghargai terhadap pluralitas justru banyak membawa implikasi negatif. Penyeragaman bukan saja mematikan kreativitas, tetapi lebih jauh juga dapat melahirkan sikap dan cara pandang yang tidak toleran. Oleh karena itu, membangun pendidikan yang berparadigma pluralis-multikultural merupakan kebutuhan yang tidak bisa ditunda lagi. Dengan paradigma semacam ini, pendidikan diharapkan akan dapat melahirkan anak didik yang memiliki cakrawala pandang luas, menghargai perbedaan, penuh toleransi, dan penghargaan terhadap segala bentuk perbedaan.” (Naim \& Sauqi, 2010)

Ngainun juga menyebutkan (pada kutipan di atas) bahwa, jika konsep pendidikan seperti ini (berbasis pluralisme) tidak diaplikasikan maka akan banyak membawa implikasi negatif terhadap perkembangan dunia pendidikan.

Menurut Mastuhu, dalam bukunya Memberdayakan Sistem Pendidikan Islam (Nata, 2005) menyebutkan bahwa:

“Masyarakat Indonesia kini dipahami sebagai sesuatu kekuatan raksasa yang mempengaruhi tata kehidupan dunia secara menyeluruh, simultan, dan berdampak multiplayer effects. Pengaruh globalisasi yang didukung oleh kemajuan ilmu pengetahuan dan teknologi dibidang komunikasi dan informasi telah merambah ke seluruh dunia dan menjamah setiap aspek kehidupan tanpa mengenal batas."(Mastuhu, 1999) 
Melihat fenomena tersebut, pendidikan di Indonesia haruslah peka dalam merespons arus perputaran globalisasi. Pola pemaksaan kehendak dari pemerintah untuk membentuk suatu kehidupan berbangsa yang seragam dalam segala aspek kehidupan perlu ditinjau ulang dan dipertanyakan. Gelombang demokrasi menuntut pengakuan perbedaan dalam tubuh bangsa Indonesia yang majemuk. Oleh sebab itu, menurut Ahmad Syafii Maarif pendidikan berbasis pluralisme adalah jawaban dari beberapa masalah dari kemajemukan itu. Syafii Maarif menyebutkan: “...pluralisme di Indonesia adalah suatu rahmat tersendiri sebagai sumber ide bagi sebuah masyarakat yang sedang berkembang dan menghadapi banyak tantangan baru." (Maarif, 2004)

Menurut Dian Lestari dalam bukunya Pendidikan Karakter: Mengarusutamakan nilai-nilai Toleransi, Anti Kekerasan dan Inklusif menyebutkan bahwa bentuk pendidikan berbasis pluralisme adalah mengupayakan agar peserta didik paham akan makna dan aplikasi dari nilai-nilai toleransi. Peserta didik mampu untuk menghargai perbedaan antar agama, serta peserta didik mampu untuk mengemukakan nilai anti kekerasan dalam menghadapi perbedaan antar agama. (Lestari, 2012) Yang menjadi dasar pendidikan berbasis pluralisme adalah QS Al-Hujurat: 12-13, Al-Maidah: 8, AlKafirun: 6 dan beberapa ayat Al-Qur'an lainnya.

Adapun tujuan pendidikan berbasis pluralisme menurut Dian adalah untuk meningkatkan jiwa toleransi peserta didik, memahamkan kepada peserta didik bahwa tidak ada paksaan dalam agama, dan melahirkan peserta didik yang saling menghargai praktik ibadah agama lain. (Lestari, 2012)

Menurut Qosim Nursheha Dzulhadi, Dampak dari konsep pendidikan berbasis pluralisme adalah akan melahirkan kelompok yang mengakui dirinya sebagai kaum liberal dan mengklaim bahwa Al-Qur'an mendukung konsep pluralisme. Dari klaim tersebut muncul persepsi bahwa semua agama itu sama. (Dzulhadi, 2013) Pendidikan Islam berbasis pluralisme akan berusaha mengikis keyakinan beragama umat Islam yang benar dan bersumber kepada Al-Qur'an dan Sunah. Hal tersebut dibuktikan dengan salah satu ungkapan seorang aktivis Muhammadiyah pada media massa (Jawa pos, 11 Januari 2004): (Husaini, 2005)

"Karena itu, mari kita memproklamasikan kembali bahwa pluralisme agama sudah menjadikan hukum Tuhan (sunatullah) yang tidak mungkin berubah. Dan karena itu, mustahil pula kita melawan dan menghindarinya. Sebagai Muslim, kita tidak punya jalan lain kecuali bersikap positif dan optimistis dalam menerima pluralisme agama sebagai hukum Tuhan"

Maarif Institute for Culture and Humanity adalah lembaga yang menyuarakan pendidikan berbasis pluralisme melalui institusi atau kelembagaan dan pemikiranpemikirannya. Hal tersebut dituliskan dalam Jurnal Maarif: Arus Pemikiran Islam dan Sosial terbitannya Maarif Institute bahwa: 
“Keberadaan Maarif Institute merupakan bagian yang tidak terpisahkan dari jaringan gerakan Pembaharuan Pemikiran Islam (PPI) yang ada di Indonesia dewasa ini. kompleksitas masalah kemanusiaan modern berikut isu-isu kontemporer yang mengikutinya seperti demokrasi, hak asasi manusia, pluralisme, gender, dialog antar agama dan peradaban. Serta sederet isu lainnya menuntut pemahaman dan penjelasannya baru dari ajaran Islam." (Jurnal Maarif Institute, Arus Pemikiran Islam dan Sosial, 2012)

Jurnal tersebut juga menjelaskan bahwa lembaga yang didirikan oleh Ahmad Syafii Maarif ini menjadikan nilai keadilan sosial dan intelektualisme pendirinya sebagai fondasi dalam pembaruan pemikiran. Nilai dasar yang diterapkan oleh lembaga ini adalah adanya egaliter, non-diskriminasi, toleran dan inklusif.

Menurut Dian Lestari (salah seorang penulis di Maarif Institute), salah satu kiprah Maarif Institute dalam dunia pendidikan telah menerbitkan buku pegangan mata pelajaran PAI tingkat SMA. Buku yang berjudul Pendidikan Karakter: Mengarusutamakan Nilai-nilai Toleransi Anti Kekerasan dan Inklusiftahun 2012 dengan jelas menjunjung tinggi nilai inklusifitas dalam beragama, toleransi dalam beragama dan pluralis dalam beragama. (Lestari, 2012)

Melalui kiprah tersebut, Maarif Institute sangat aktif dalam menyebarkan nilai-nilai pluralisme dalam pendidikan. Contohnya, Maarif Institute berhasil bekerja sama dengan Dinas Pendidikan di beberapa kabupaten. Di antaranya: Dinas Pendidikan Pemuda dan Olahraga Kota Surakarta, Dinas Pendidikan Kota Yogyakarta, Dinas Pendidikan Kabupaten Pandeglang dan Dinas Pendidikan Kabupaten Cianjur. Hasil kerja sama antara Maarif Institute dengan beberapa Dinas kota atau kabupaten tersebut, terealisasi dengan adanya kata sambutan Kepala Dinas Kota atau Kabupaten tersebut pada buku terbitan Maarif Institute. (Lestari, 2012)

Selain lembaga, beberapa tokoh yang mendukung pemikiran pendidikan berbasis pluralisme dan multikultural, di antaranya Choirul Mahfud dengan bukunya yang berjudul Pendidikan Multikultural (Pustaka Pelajar) tahun 2010, Ngainun Nuim dalam bukunya Pendidikan Multikultural Konsep dan Aplikatif (Ar-Ruzz Media) tahun 2010, Zakiyuddin Baidhawy dengan bukunya yang berjudul Pendidikan Agama Berwawasan Multikultural (Gelora Aksara Pratama) tahun 2005. Kemudian Ahmad Syafii Maarif yang secara tidak langsung menyebarkan benih-benih pluralisme dan mulkulturalisme dalam pendidikan. Salah satu contoh wacana pluralisme Ahmad Syafii Maarif adalah seperti yang dituliskan oleh R William Liddle pada pengantar buku Mencari Autentisitas dalam Kegalauan karya Prof. Ahmad Syafii Maarif:

"Syafii mencita-citakan sebuah Indonesia yang egaliter secara sosial, ekonomi, politik, dan betul-betul demokratis. Pemerintah harus bertanggung jawab kepada rakyat melalui pemilihan umum yang free and fair, bebas dan tidak berpihak. 
Lembaga pemilu arus didukung oleh lembaga pemerintah lain, khususnya kehakiman yang mandiri, dan lembaga non-pemerintah seperti partai, organisasi masyarakat dan pers yang bebas pula." (Maarif, 2004)

Dalam paragraf lain William Liddle juga menuliskan:

"Syafii juga bersikap terbuka kepada masukan dari agama dan masyarakat lain. Dia tentu percaya bahwa Islam adalah agama yang paling benar dan Nabi Muhammad adalah rasul penutup. Namun, sekaligus dia memahami bahwa yang menafsirkan firman Tuhan adalah manusia, dengan segala kekurangan dan kelemahannya. Dalam konteks itu, pluralisme agama di Indonesia adalah suatu rahmat tersendiri sebagai sumber ide bagi sebuah masyarakat yang sedang berkembang dan menghadapi banyak tantangan baru. Ketika Syafii membicarakan konsep masyarakat madani (yang Islami), dia mengaku diilhami antara lain oleh pengalaman masyarakat Kristen dan Barat pada umumnya." (Maarif, 2004)

Menurut Syafii Maarif, untuk menjawab dan menyelesaikan masalah bangsa yang ada saat ini maka perlulah dilakukan dialog lintas agama untuk mencari solusi demi kebaikan kolektif warga Indonesia. Sebuah agama apabila dipahami dengan benar dan cerdas, pasti akan mendorong pemeluknya untuk mengembangkan budaya dialogis, bukan budaya saling mengunci pintu.

Konsep pluralisme merupakan bagian dari liberalisasi. (Barton, 1999) Di Indonesia kemunculan gerakan liberalisasi ini tidak terlepas dari persoalan multidimensi yang sedang melilit masyarakat Indonesia saat ini. (Syafin, 2007) Dan pendidikan berbasis pluralisme ditawarkan sebagai solusi dari persoalan-persoalan tersebut. (Maarif, 2004)

Berdasarkan pada uraian di atas, tampak adanya perbedaan tujuan pendidikan Islam dengan pendidikan berbasis pluralisme. Perbedaannya juga terlihat pada kurikulum yang disampaikan pada konsep pendidikan berbasis pluralisme dan konsep pendidikan Islam. Konsep pendidikan berbasis pluralisme sangat bertolak dengan konsep pendidikan dalam Islam.

\section{Metode Penelitian}

Penelitian ini termasuk jenis penelitian kepustakaan (library research). Sumber data yang digunakan ialah seluruh buku terbitan Maarif Institute yang sejenis dengan liberalisasi, pluralisme pendidikan. Dalam penelitian ini buku yang menjadi data primer adalah buku Pendidikan Karakter: Mangarusutamakan Nilai-nilai Toleransi Anti Kekerasan dan Inklusif, Jurnal-jurnal Maarif Institute yang dibukukan. Pendidikan Multikultural karangan Choirul Mahfud, buku Pendidikan Multikultural Konsep dan Aplikasi karangan Ngainun Naim dan Achmad Sauqi.

Analisis dalam penelitian ini adalah seluruh rangkaian kegiatan sebagai upaya menarik kesimpulan dari hasil kajian konsep atau teori yang mendukung penelitian ini. 
Dalam menganalisis data digunakan analisis isi atau content analysis dengan metode analitic-kritis. Content analysis adalah suatu teknik untuk membuat inferensi-inferensi (simpulan) yang dapat ditiru dan sahih data dengan memperhatikan konteksnya. Pada penelitian ini, digunakannya metode ini untuk menganalisis studi kritis terhadap konsep pendidikan berbasis pluralisme oleh Maarif Institute.

\section{Hasil dan Pembahasan}

\section{A. Pendidikan Berbasis Pluralisme di Maarif Institute}

\section{Landasan Pendidikan Berbasis Pluralisme}

Berdasarkan kepada kata pengantar yang ditulis di Jurnal Maarif (pada pembahasan poin A), jelas disebutkan bahwa Maarif Institute sangat menjunjung nilai-nilai pluralisme. Nilai tersebut diterapkan melalui jalur pendidikan, lebih spesifiknya dengan menerbitkan buku-buku yang menguraikan nilai-nilai inklusif, salah satu bukunya adalah Pendidikan Karakter: Mengarusutamakan Nilai-nilai Toleransi Anti Kekerasan dan Inklusiftahun 2012. Buku ini ditulis oleh Dian Lestari, S.Ag. dan Drs. Hamid Supriyanto dan editornya Muhammad Abdullah Darraz dan Khelmy K Pribadi. Buku ini merupakan wajah dari Maarif Institute untuk mengembang nilai pluralisme. Toleransi dalam beragama dan anti kekerasan.

Beberapa hal yang menjadi landasan bagi Maarif Institute dalam mengembangkan Pendidikan berbasis pluralisme.

a. Pada kolam ringkasan materi bab 1 buku Pendidikan Karakter: Mengarusutamakan Nilai-nilai Toleransi Anti Kekerasan dan Inklusif di tuliskan bahwa Islam mengajarkan sikap toleran dalam kehidupan, terutama dalam kehidupan beragama. Toleransi dalam bentuk pikiran, sikap dan perilaku yang ditujukan untuk merajut persaudaraan dan harmoni di dalam tubuh satu umat beragama, dan antar umat beragama. (Lestari, 2012)

b. Maarif Institute berdalih toleransi dalam bentuk pikiran adalah berpikir positif ( $h u s n$ al-zhan) terhadap perbedaan agama, etnik dan kultur dalam Al-Qur'an surat AlHujurat: 13

c. Selain toleransi dalam pikiran, Maarif juga menguraikan toleransi dalam sikap. Yaitu berprasangka baik terhadap siapa pun yang bukan bagian dari kita atau siapa pun di luar diri kita.

d. Bentuk toleransi berikutnya adalah toleransi dalam perilaku, adalah bertindak adil terhadap siapa pun tanpa kebencian. Berdalihkan kepada QS. Al-Maidah: 8

e. Penyebaran nilai-nilai Toleransi dan Pluralisme Agama. 
Maarif Institute menyebarkan nilai pluralisme agama dengan membuat definisi pluralisme agama dalam buku terbitannya. Agama Islam merupakan agama cinta damai, sesuai akar katanya, "salam”. Oleh karenanya Islam sangat menghargai dan mengakui realitas kemajemukan seperti suku, golongan, dan agama. Fahma inilah yang Maarif Institute istilah dengan pluralisme.(Lestari, 2012)

Maarif Institute berpendapat bahwa pada konteks pluralisme agama, penghargaan dan pengakuan terhadap pluralitas agama tidak serta merta menyamakan antara satu agama dengan agama lainnya. Pluralisme agama justru menegaskan bahwa setiap agama memiliki perbedaannya masing-masing, dan perbedaan ini harus dapat diterima sebagai sebuah realitas dalam kehidupan.

Q.S. Al-Kafiri: 6 yang berbunyi "untukmu agamamu dan untukku agamaku" dijadikan isyarat oleh Maarif Institute tentang pluralisme. Pluralisme agama merupakan perwujudan dari kehendak Allah SWT agar manusia berlomba-lomba dalam kebaikan. Dia (Allah SWT) tidak menginginkan hanya ada satu agama walaupun sebenarnya Allah punya kemampuan untuk melakukan hal itu bila Dia menghendaki.

Dalam buku Materi Pengayaan Mata Pelajaran Pendidikan Agama Islam untuk SMA tersebut, Dian Lestari menguraikan bahwa Al-Qur'an bukan hanya mengakui perbedaan dan pluralitas agama, lebih jauh Al-Qur'an juga mengakui keberadaan golongangolongan non-agama.

Untuk memperkuat argumennya, Maarif Institute memberikan clue-clue bagaimana caranya agar toleransi sesama manusia bisa terjaga dengan baik tanpa menimbulkan masalah. Di antaranya clue-clue tersebut adalah: 1) mengakui hak orang lain. Sebagai seorang yang bermartabat sudah selayaknya mengakui hak orang lain dan hal tersebut mesti dihormati. 2) menghormati keyakinan orang lain. Dalam masalah keyakinan, selama orang tersebut tidak menyinggung atau mengganggu terhadap keyakinan kita, maka kita pun harus menghormati keyakinan mereka. 3) Agree in disagreement (sepakat dalam perbedaan). Sepakat adalah bentuk persetujuan terhadap segala perbedaan yang ada. 4) saling mengerti. Ini merupakan salah satu unsur toleransi yang paling penting, sebab dengan tidak adanya saling pengertian tentu toleransi tidak akan terwujud, dan 5) kesadaran dan kejujuran tentang siapa dirinya dan pemahaman terhadap diri orang lain akan menyebabkan timbulnya toleransi.

\section{Tujuan Pendidikan Berbasis Pluralisme}

\section{a. Meningkatkan Jiwa Toleransi}

Berdasarkan kepada landasan pendidikan berbasis pluralisme di atas, dapat dipahami bahwa secara umum tujuan pendidikan berbasis pluralisme adalah menciptakan lulusan-lulusan pendidikan yang berjiwa toleransi antara agama, berjiwa 
inklusif, demokrasi dan paham pluralisme agama. Dengan adanya jiwa toleransi pada peserta didik, maka jiwa menenggang dalam perbedaan akan terwujud dengan sendirinya.

Dian Lestari menuliskan makna mengenai toleransi:

“Toleransi berarti menenggang perbedaan, antara mayoritas dan minoritas tidak terkotak-kotak. Toleransi tertanam dari pikiran, tercermin dalam sikap dan mengejawantah dalam perilaku. Dengan jiwa toleransi dapat menjadi modal utama untuk menciptakan kerukunan dan keadilan dalam kehidupan di dunia. Sama-sama dipahami bahwa realitas kehidupan sangat beragam, karakter toleran adalah kesediaan untuk menerima dan menghargai realitas yang majemuk tersebut." (Lestari, 2012)

\section{b. Dalam lingkup hak beragama}

Maarif Institute berdalih bahwa "tidak ada paksaan dalam agama", Islam menjamin dan melindungi hak orang lain untuk memilih agama dan keyakinannya. Agama merupakan pilihan yang paling penting dan mendasar dalam kehidupan manusia. setiap orang memiliki kebebasan untuk memilih agama yang diyakininya, jika seseorang sudah menentukan agama yang diyakininya, maka kita harus menghormatinya. Orang lian tidak memiliki kewenangan untuk memerintahnya untuk keluar dari agama tersebut.

Munculnya berbagai aksi kekerasan, khususnya yang mengatasnamakan agama, suku, dan kelompok tertentu, menimbulkan berbagai pandangan seakan-akan kehidupan beragama di Indonesia sudah berada pada kondisi kritis karena memudarnya rasa toleransi terhadap kemajemukan. Konflik intra dan antar agama tidak hentihentinya mewarnai kehidupan berbangsa dan bernegara sehingga korban pun terus berjatuhan. Ironisnya, tokoh agama dan masyarakat belum mampu berbuat banyak. Sama-sama disepakati bahwa kekerasan bukanlah sebagai penyelesai masalah.

Fajar Riza UI Haq dalam Jurnal Maarif menuliskan satu contoh akibat kekerasan terhadap kaum minoritas, yaitu kekerasan terhadap Ahmadiyah. Menurut Fajar pembiaran terhadap aksi-aksi intoleransi tersebut merupakan sebuah anomali dalam proses demokratisasi. Fajar menuliskan:

"Berlarutnya penyelesaian berbagai kasus-kasus seperti kasus lemahnya perlindungan terhadap Ahmadiyah dan penyelesaian kasus korupsi kakap telah menimbulkan defisit kepercayaan publik terhadap pemerintah saat ini. Dalam hal perlindungan terhadap kelompok minoritas justru semakin meningkat pada tahun 2010 . Pembiaran aksi-aksi intoleransi tersebut merupakan sebuah anomali dalam proses demokrasi. (Haq, 2011) "Masa depan demokrasi Indonesia yang masih belia terancam jika aparat negara dan kelompok berbasis keagamaan tidak meredam kekerasan yang terjadi”. (Haq, n.d.) 
Berdasarkan kepada permasalahan tersebut, maka tujuan pendidikan ini dalam lingkup hidup antar agama adalah memahamkan kepada peserta didik bahwa setiap manusia memiliki hak untuk memilih agama berdasarkan keyakinannya masing-masing. Kemudian diperkuat dengan menegaskan bahwa ajaran Islam memegang teguh prinsip "tidak ada paksaan dalam beragama". Dan diterapkan juga peserta didik tidak akan melakukan pemaksaan ataupun ancaman terhadap kelompok agama/keagamaan lain yang berbeda pilihan.

\section{c. Dalam lingkup hak menjalankan praktik keagamaan}

Setiap umat beragama berhak menjalankan agama dan kepercayaannya dalam bentuk ajaran, praktik, ibadah, dan ketaatan sesuai dengan ajaran agamanya. Dalam sub bab buku materi pengayaan pendidikan karakter dituliskan bahwa hak menjalankan agama dijamin oleh Undang-Undang Dasar 1945 Pasal 29 Ayat 2. Oleh karena itu umat beragama secara individu maupun kolektif dapat melaksanakan agamanya tanpa rasa takut dan terancam. Berdasarkan UUD tersebut juga negara wajib menjadi penjamin dan pelindung atas kebebasan menjalankan agama dan kepercayaan setiap warga negara.

Maarif Institute menjadikan QS. Al-Baqarah ayat 144 sebagai dalih bahwa Al-Qur'an memberikan jaminan menjalankan agama. Selain ada hak untuk menjalankan praktik keagamaan, hak mendirikan tempat ibadah juga dimiliki oleh semua agama. Setiap umat beragama berhak mendirikan tempat ibadah yang digunakan untuk menyembah Tuhan sesuai tata cara yang ditentukan. Untuk tetap dapat menjaga kerukunan dan rasa toleransi diperlukan adanya kesadaran bersama antar pemeluk agama. Perlunya mematuhi bersama dalam pendidikan tempat ibadah. Dalam hal ini pemerintah memiliki kewajiban untuk mengatur dan melindungi setiap umat beragama. Salah satu bentuk perlindungan itu adalah dengan memberikan hak bagi pemeluk agama untuk mendirikan tempat ibadah.

Berdasarkan permasalahan tersebut, memahamkan kepada peserta didik bahwa adanya perbedaan dalam menjalankan praktik keagamaan setiap pemeluk agama menjadi salah satu visi dan tujuan dari Maarif Institut dalam pendidikan berbasis pluralisme. Kemudian Maarif Institute mengajarkan kepada para penuntut ilmu/peserta didik untuk menerapkan dan membiasakan perilaku toleran terhadap pemeluk agama lain dalam praktik kehidupan sehari-hari.

\section{Kurikulum Pendidikan Berbasis Pluralisme}

Untuk menjunjung tinggi nilai-nilai pluralisme dan toleransi antar agama melalui media pendidikan, Maarif Institute merangkap materi yang beraruskan kepada Pembentukan Pendidikan Karakter. Pendidikan karakter merupakan upaya jawaban dari Pemerintah Presiden Susilo Bambang Yudoyono (2009-2014) terhadap krisis 
identitas kebangsaan dan persoalan sosial di kalangan generasi muda khususnya pelajar. Karena Maarif Institute melihat bahwa tiga tahun terakhir ini angka tawuran pelajar, aksi kekerasan yang melibatkan remaja semakin meningkat. Dan berkembangnya pandangan yang tidak menghargai perbedaan (intoleran) di lingkungan sekolah. Di lingkungan sekolah, paling tidak beberapa tahun terakhir ini telah memunculkan desakan dari berbagai pihak kepada pemerintah untuk mengembalikan fungsi kreatif, kritis, reflektif, patriotik, dan humanis dari pendidikan.

Maarif Institute menyusun kurikulum pendidikan berbasis pluralisme bertitik tolak kepada tiga nilai yaitu: penguatan nilai-nilai toleransi, anti kekerasan, dan inklusif/keterbukaan.

Gabungan dari ketiga materi (Toleransi, Anti Kekerasan dan Inklusif) tersebut, secara tidak sengaja telah menyemaikan "benih-benih" pluralisme agama. Adapun alur materi yang diberikan adalah sebagaimana yang tertera pada tabel berikut:

\begin{tabular}{ll}
\hline \multicolumn{1}{c}{ Kelompok Materi } & \multicolumn{1}{c}{ Materi } \\
\hline Toleransi & Toleransi \\
& Hak Beragama \\
& Hak Menjalankan Praktik Keagamaan \\
& Dakwah: Mengajak Tanpa Memaksa \\
& Berlaku Adil Terhadap Perbedaan \\
\hline Anti Kekerasan & Anti Kekerasan \\
& Demokrasi \\
& Memahami dan Mengelola Konflik \\
& Mengakui Kesalahan \\
& Memberi Maaf \\
\hline Inklusifitas & Berlomba dalam kebaikan \\
& Menghargai Karya dan Budaya Bangsa Lain \\
& Inklusif Sebagai Semangat Peradaban Islam \\
& Karakter Inklusif Islam Nusantara \\
\hline
\end{tabular}

Sumber: Dian Lestari, Pendidikan Karakter: Mengarusutamakan Nilai-nilai Toleransi Anti Kekerasan dan Inklusif, Jakarta: Maarif Institute, 2012, hlm. xxi

\section{Nilai-nilai Pluralisme di Maarif Institute}

Dalam mengembangkan nilai-nilai pluralismenya, Maarif Institute mengemasnya dalam tiga term utama. Melalui tiga term itulah, Maarif Institute memahamkan masyarakat, lembaga pendidikan dan simpatisannya seputar nilai-nilai pluralisme yang diikuti. Hal tersebut dilakukan dengan berbagai programnya. Tiga term tersebut adalah: nilai-nilai toleransi, anti kekerasan dan inklusifitas/keterbukaan. Berikut penulis menguraikan satu per satu makna ketiga term tersebut menurut Maarif Institute:

\section{a. Nilia-nilai toleransi}

Dian Lestari yang mengutip dari Kamus Besar Bahasa Indonesia Pusat Bahasa, Departemen Pendidikan Nasional (Jakarta: Gramedia Pustaka Utama, 2008) mendefinisikan toleran adalah bersikap menenggang (menghargai, membiarkan dan 
membolehkan) pendirian (pendapat, pandangan, kepercayaan, kebiasaan) yang berbeda atau bertentangan dengan pendirian sendiri. Adapun yang menjadi landasan kurikulum oleh Maarif Institute terkait hal ini adalah terbentuknya mentalitas dan pembudayaan perilaku peserta didik untuk bersikap hormat terhadap perbedaan pandangan, suku, agama, pilihan politik dan afiliasi keagamaan sekaligus mengakui hakhaknya untuk hidup dan berkembang dalam perbedaan itu.

Pada nilai-nilai toleransi ini, Maarif Institute mengajarkan bagaimana masyarakat (peserta didik) paham akan nilai-nilai toleransi dan implementasinya, hak beragama, hak dalam menjalankan praktik keagamaan, dalam ranah dakwah yaitu mengajak tanpa memaksa dan berlaku adil terhadap perbedaan.

\section{b. Anti kekerasan}

Kekerasan adalah perbuatan seseorang atau kelompok yang menyebabkan cedera atau matinya orang lain. Atau menyebabkan perusakan fisik dan barang orang lain. Adapun yang menjadi landasan kurikulum oleh Maarif Institute terkait hal ini adalah kemampuan setiap peserta didik secara aktif mencegah dirinya dan orang yang melakukan upaya provokasi, menyebar kebencian, dan aksi kekerasan terhadap pihak lain, baik kekerasan fisik maupun kekerasan verbal.

Pada term ini, Maarif Institute mengajarkan nilai-nilai anti kekerasan serta bagaimana implementasinya. Nilai-nilai demokrasi dalam masyarakat, bagaimana memahami dan mengelola konflik, belajar mengakui kesalahan dan menerapkan sikap memberi maaf.

Di antara nilai anti kekerasan yang diajarkan oleh Maarif Institute lebih kepada bagaimana memaknai jihad. Dian menuliskan dalam bukunya bahwa:

“... jihad tidak sama dengan qital. Qital adalah berperang melawan orang-orang yang memusuhi Islam. Adapun jihad dilakukan dengan perbuatan atau harta yang dimiliki, jihad juga dilakukan melalui pemikiran-pemikiran, karya-karya nyata, mendalami ilmu pengetahuan dan teknologi, berbuat baik, berlaku adil, dan selalu mengusahakan perdamaian. Itulah makna jihad yang sejati. Bahkan Rasulullah menunjukkan bahwa jihad yang paling besar dan berat adalah jihad menahan hawa nafsu, seperti nafsu berbuat kekerasan, perusakan, dan berbagai kejahatan di bumi. Jadi, jihad bukanlah doktrin perang."

“jihad perlu dimaknai secara luas, bukan dengan melakukan kekerasan atas nama agama. Agama kita memang perlu dibela dan dipertahankan agar tidak dilecehkan oleh siapa pun, tetapi semua itu harus dilakukan dengan cara-cara yang santun penuh hikmah, bukan dengan melakukan tindak kekerasan." (Lestari, 2012)

\section{c. Inklusif/keterbukaan}


Keterbukaan hati merupakan awal dari mulainya komunikasi. Untuk mengartikan inklusif, Dian Lestari mengambil terjemah dari Alwi Shihab. Adapun karakter inklusif yang ingin dituju adalah adanya kesediaan peserta didik untuk membuka hal-hal baru positif, keaktifan untuk berdialog dengan pihak lain guna mencari kebenaran dan kemaslahatan bersama, dan menenggang kelompok lain untuk menjalankan kewajiban sesuai keyakinan dan agamanya.

Terkait Inklusif, Dian menambah penegasannya bahwa Islam harus mengikuti budaya nusantara, karena Islam datang belakangan dari pada budaya dan nusantara. dengan menulis bahwa:

"Sebelum Islam masuk ke Indonesia, Indonesia sudah terbentuk dan berkembang berbagai budaya, kepercayaan dan agama. Kemudian Islam datang sebagai agama baru yang berkembang di lingkaran sejarah budaya nusantara. Oleh karenanya kehadiran Islam adalah bagian dari perjalanan panjang sejarah bangsa ini, Islam telah memberikan warna kebudayaan bagi sejarah bangsa ini. Maka Islam tidak seharusnya dipisahkan atau dipertentangkan dengan budaya nusantara." (Lestari, 2012)

Dari ungkapan di atas jelas terlihat bahwa, menurut Dian Islam harus mengikuti atau menyesuaikan dengan budaya dan kebiasaan yang sudah ada sebelum Islam. ini merupakan sebuah pemikiran yang fatal dan salah. Karena sudah jauh lebih dahulu ada dan telah mengatur semuanya. Jadi sangat tidak sesuai sekali jika Islam yang harus menyesuaikan dengan kebudayaan nusantara.

Pada term inklusifitas ini, Maarif Institute mengajarkan nilai-nilai berlomba-lomba dalam kebaikan, bagaimana menghargai karya dan budaya bangsa lain. Selain itu juga mengajarkan bahwa inklusif sebagai semangat peradaban Islam dan mengklasifikasikan karakter inklusif Islam nusantara.

\section{B. Pendidikan Berbasis Pluralisme di Maarif Institut dan Kritikannya}

Untuk menemukan hasil akhir dari penelitian ini, maka perlu melakukan analisis studi kritis terhadap konsep pendidikan berbasis pluralisme yang ditawarkan oleh Maarif Institute tersebut. Hal tersebut dilakukan sebagai berikut:

\section{Landasan Pendidikan Islam}

Yang disebut dengan landasan pendidikan adalah konsep dasar pendidikan. Yang menjadi landasan oleh Maarif Institute dalam mengelola pendidikan adalah nilai-nilai pluralisme yang akrab disapa dengan pendidikan berbasis pluralisme. Untuk mengembangkan nilai pluralisme tersebut, Maarif Institute mengemasnya dalam tiga term, yaitu: mengutamakan nilai-nilai toleransi, inklusifitas, dan nilai-nilai anti kekerasan. (Lestari, 2012) Sehingga dengan landasan tersebut berpengaruh kepada materi-materi yang disampaikan. Pada materi tersebut terdapat nilai-nilai pluralisme 
yang di kembangkan, hal inilah yang bertolak belakang dengan nilai-nilai pendidikan Islam.

Inilah hal yang perlu dikritisi, bahwa sumber asasi ajaran Islam adalah Al-Qur'an dan Hadist, tidak hanya berisikan doktrin-doktrin teologis tentang keimanan kepada Allah SWT, tetapi juga mengandung isyarat-isyarat ilmiah tentang pendidikan. Karenanya, membicarakan konsep dasar pendidikan dalam Islam, haruslah merujuk kepada informasi yang tertera dalam Al-Qur'an dan Hadist.(Rasyidin, 2008) Mengenai hal ini, Al Rasyidin lebih menjelaskan tentang konsep dasar pendidikan Islam, setidaknya ada tiga term yang digunakan Al-Qur'an dan Hadist yaitu memahami dan memaknai tarbiyah, ta'lim dan ta'dib.

Pendapat Al Rasyidin tersebut diperkuat oleh Abdurraman An-Nahlawi yang mengatakan bahwa dasar pendidikan Islam adalah agama Islam itu sendiri, termasuk dua sumber utamanya yaitu Al-Qur'an dan Sunah. Dalam dimensi pendidikan yang lebih luas, agama sebagai dasar operasional pendidikan dan menjadi frame bagi semua aktivitas kependidikan. Asas atau dasar pendidikan agama adalah dalam Islam terbagi kepada tiga bagian, yaitu dasar ideal, dasar ta'abbudi dan dasar tasyri’i. (An-Nahlawi, 1996)

Bertolak belakang dengan Maarif Institute, Dilihat dari buku Falsafah Pendidikan Islam dituliskan oleh Al Rasyidin, bahwa yang menjadi landasan pendidikan Islam dapat dibagi kepada tiga tahap, yaitu: (Rasyidin, 2008)

\section{Landasan Ontologis Pendidikan Islam}

Dalam landasan ontologis ini dibahas mengenai konsep alam semesta perspektif pendidikan Islam. proses penciptaan alam semesta, tujuan penciptaan alam semesta. Tujuan hal ini dijadikan sebagai landasan pendidikan adalah menghantarkan manusia untuk mengetahui Kemahakuasaan Allah SWT, dengan demikian akan membantu mendekatkan manusia untuk lebih bertaqorrub kepada Sang Penciptanya. Implikasinya terhadap pendidikan Islam bahwa Dia adalah Rabb yaitu Tuhan Maha Pencipta (Khaliq) yang menciptakan seluruh makhluk. Karenanya Dia disebut Rabbul 'alamin yaitu Tuhan Pencipta Alam Semesta. Selain pencipta, Dia juga memelihara dan mendirikan seluruh alam. (Shihab, 2004)

Selain membahas konsep alam, juga membicarakan tentang konsep manusia dalam pendidikan. Mengenai proses penciptaan manusia, tujuan dan fungsi diciptakannya manusia, tugas manusia diciptakan ke muka bumi dan bagaimana manusia menurut manusia (menurut pemikir Muslim dan menurut Pemikir Barat) serta manusia menurut Al-Qur'an. Implikasinya terhadap dunia pendidikan Islam bahwa manusia adalah makhluk yang nyata-nyata ada dan terlihat. Keberadaan manusia tersebut selalu mengalami perkembangan, perkembangannya tersebut harus dibantu oleh pendidikan. 
Selain itu juga membantu manusia untuk mengembangkan potensi-potensi yang ada pada individu manusia. Al Rasyidin menjelaskan bahwa manusia terdiri dari dua dimensi, yaitu dimensi material dan dimensi non material, untuk mengembangkan kedua dimensi tersebut pendidikanlah yang harus berpartisipasi aktif.

Hal terakhir yang menjadi landasan ontologis pendidikan Islam adalah mengetahui tentang konsep masyarakat Islam, karakteristik masyarakat Islam. hal ini berimplikasi dengan pendidikan Islam bahwa pendidikan adalah aktivitas khas masyarakat manusia, dan pendidikan dijadikan sebagai sarana atau instrumen bagi upaya membentuk dan mewujudkan tatanan masyarakat Islami yang ideal. (Rasyidin, 2008)

\section{Landasan Epistemologi Pendidikan Islam}

Landasan epistemologi dalam pendidikan Islam mengkaji tentang konsep ilmu dan bagaimana karakteristik ilmuan Muslim menurut pendidikan Islam. salah satu unsur terpenting dalam pendidikan Islam adalah ilmu. Pada pembahasan ini dipahami bahwa hakikat sebuah pendidikan adalah transfer of knowledge atau penanaman ilmu ke dalam diri manusia. oleh karenanya jika berbicara mengenai dunia pendidikan Islam, tidak akan terpisahkan dengan pembicaraan tentang ilmu.

Mengutip pendapat Al Rasyidin bahwa aspek-aspek yang harus dipahami pada landasan epistemologi ini adalah mulai dari mengetahui makna ilmu pengetahuan, sumber-sumber ilmu pengetahuan, instrumen dalam meraih ilmu pengetahuan, tujuan pencarian ilmu pengetahuan dan bagaimana karakteristik ilmu pengetahuan islami.

Merujuk kepada pengertian ilmu menurut Al-Ghazali, beliau mengatakan bahwa IImu dalam bahasa arab, berasal dari kata kerja 'alima yang bermakna mengetahui. Jadi ilmu itu adalah masdar atau kata benda abstrak dan kalau dilanjutkan lagi menjadi 'alim, yaitu orang yang tahu atau subjek, sedang yang menjadi objek ilmu disebut ma'lum, atau yang diketahui. Dalam proses perkembangan ilmu, lalu ilmu dipakai dalam dua hal: yaitu sebagai mashdar atau proses pencapaian ilmu dan sebagai objek ilmu (ma'lum).

Al-Ghazali menggunakan kedua makna ilmu itu dalam tulisan-tulisannya. Tentang ilmu sebagai proses Al-Ghazali menceritakan tentang ilmu-ilmu Indera (hissiyah), ilmuilmu akal (aqliyah) dan ilmu ladunni. Dengan kata lain ada ilmu-ilmu melalui pancaindra, dan melalui akal, ada yang tidak melalui pancaindra dan akal, tetapi langsung terus ke hati, itulah ladunni atau langsung dari Allah. Tentang ilmu sebagai objek dapat kita lihat pada kritikan Al-Ghazali terhadap golongan ilmu kalam, golongan batiniah dan terutama terhadap golongan ahli falsafah. (Langulung, 1989) 


\section{Landasan Aksiologi Pendidikan Islam}

Pada landasan aksiologi ini mengkaji tentang kepribadian manusia, terkhusus kepada pendidikan akhlak dan proses pembentukan kepribadian Muslim. Hal ini dirasa penting sekali karena tujuan pendidikan Islam adalah membentuk insan kamil.

Secara bahasa akhlak berasal dari bahas Arab, yaitu asal kata khuluqun yang berarti tabiat atau budi pekerti. Sedangkan secara terminologi didefinisikan secara variatif. Ibn Miskawaih mendefinisikan sebagai suatu keadaan jiwa atau sikap mental yang menyebabkan individu bertindak tanpa berpikir atau mempertimbangkan secara mendalam. (Miskawaih, 1329) Dalam perspektif Islam, akhlak merupakan prinsip, kaidah-kaidah dan norma fundamental yang menata idealistis interaksi manusia dengan Khaliknya yaitu Allah SWT, dengan dirinya sendiri, dengan sesama manusia dan dengan alam semesta.

Pendidikan akhlak ini sangat penting, karena bertujuan untuk memelihara diri manusia agar selalu berada dalam fitrahnya. Selain itu juga untuk menanamkan prinsipprinsip, kaidah-kaidah atau norma-norma tentang baik dan buruknya kepribadian manusia (peserta didik).

Al Rasyidin memaknai kepribadian adalah sifat atau karakter yang membedakan seseorang dengan yang lainnya. Dalam proses pembentukan kepribadian manusia (peserta didik), harus berdasarkan kepada cara Rasulullah dalam melakukan praktik pendidikan kepada para sahabat, sanak saudara dan keluarganya. Pendidikan pada dasarnya adalah instrumen untuk meneguhkan kembali syahadah yang telah diikrarkan manusia kepada Tuhannya. Pendidikan seperti inilah yang telah menghasilkan generasi Muslim yang memiliki kepribadian yang kokoh. (Rasyidin, 2008)

Dalam tataran partikal, proses pembentukan, pembinaan, dan pengembangan kepribadian Islami itu diawali dari tazkiyah kemudian berlanjut ke ta'lim, tarbiyah, dan ta'dib. Karenanya, pendidikan Islam harus mampu tampil secara kondusif untuk mengembangkan nilai-nilai yang ada pada manusia (peserta didik) tersebut.

\section{Tujuan Pendidikan Islam}

Berdasarkan pada uraian di bab sebelumnya bahwa tujuan pendidikan menurut Maarif Institute adalah melahirkan lulusan-lulusan pendidikan yang paham akan nilainilai pluralisme dan mampu mengaplikasikan nilai-nilai pluralismenya dalam kehidupan. (Lestari, 2012) Nilai-nilai pluralisme yang dimaksud adalah nilai-nilai toleransi antar agama, inklusifitas dan anti kekerasan yang mengatasnamakan golongan.

Dalam menyusun rancangan pengolahan pendidikan, hal ini tidak sesuai dengan tujuan pendidikan dalam Islam. berbagai tokoh pendidikan mengungkapkan pemikirannya terkait dengan tujuan pendidikan ini. Abdurrahman An-Nahlawi 
misalnya, menyatakan bahwa tujuan pendidikan Islam adalah merealisasikan ubudiyyah dan beribadah kepada Allah SWT di dalam kehidupan manusia, baik individu maupun masyarakat. Pendidikan dalam Islam bertujuan untuk mengembangkan pikiran manusia dan mengatur tingkah laku serta perasaannya berdasarkan Islam.

Disusul oleh Al-Ghazali yang mengungkapkan bahwa tujuan pendidikan harus mengarah kepada realisasi tujuan keagamaan dan akhlak, dengan titik penekanannya pada perolehan keutamaan dan taqorrub kepada Allah dan bukan untuk mencari kedudukan yang tinggi atau mendapatkan kemegahan dunia. Sebab jika tujuan pendidikan diarahkan selain untuk mendekatkan diri kepada Allah, akan menyebabkan kesesatan dan kemudaratan.

Al-Ghazali berkata: "hasil dari ilmu sesungguhnya ialah mendekatkan diri kepada Allah, dan menghubungkan diri dengan para malaikat yang tinggi dan bergaul dengan alam arwah, itu semua adalah kebesaran, pengaruh pemerintahan bagi raja-raja dan penghormatan secara naluri." Perumusan tujuan tersebut juga diamini juga oleh Prof. Abuddin Nata, yang menyatakan bahwa tujuan pendidikan adalah menjadikan ibadah kepada Allah atas segala aktivitas manusia.

Menurut al-Ghazali, pendekatan diri kepada Allah merupakan tujuan pendidikan. Orang dapat mendekatkan diri kepada Allah hanya setelah memperoleh ilmu pengetahuan. IImu pengetahuan itu tidak akan diperoleh kecuali melalui pengajaran.

Kesimpulan tujuan pendidikan menurut Al-Ghazali dapat diklasifikasikan ke dalam beberapa poin berikut:

a. Mendekatkan diri kepada Allah, yang wujudnya adalah kemampuan dan dengan kesadaran diri melaksanakan ibadah wajib dan sunah.

b. Menggali dan mengambangkan potensi atau fitrah manusia.

c. Mewujudkan profesionalitas manusia untuk mengemban tugas keduniaan dengan sebaik-baiknya.

d. Membentuk manusia yang berakhlak mulia, suci jiwanya dari kerendahan budi dan sifat-sifat tercela.

e. Mengembangkan sifat-sifat manusia yang utama sehingga menjadi manusia yang manusiawi.

Dalam perspektif Falsafah Pendidikan Islam, tujuan tertinggi pendidikan Islam adalah menciptakan manusia Muslim yang beryahadah kepada Allah SWT. Oleh karenanya, dalam tataran partikal segala aspek-aspek dalam pendidikan Islam diarahkan kepada pencapaian tujuan tersebut. Dan dalam tataran operasional, rumusan tujuan pendidikan Islami merujuk kepada dua hal pokok, yaitu:

a. Tujuan, fungsi dan tugas penciptaan manusia oleh Allah SWT adalah sebagai syuhud, 'abd Allah dan khalifah fil ardh, maka pendidikan Islam bertujuan untuk 
mengembangkan potensi fitrah tauhid manusia agar mereka memiliki kapasitas untuk merealisasikan syahadah terhadap Allah sepanjang kehidupan di muka bumi. Selain itu juga mengembangkan potensi ilahiyah manusia agar mereka berkemampuan untuk membimbing dan mengarahkan, merealisasikan dan mengaktualisasikan diri dan masyarakatnya untuk beribadah kepada Allah SWT. Setelah potensi ilahiyahnya. Pendidikan juga bertujuan untuk bisa mengembangkan potensi insaniyahnya agar manusia memiliki kemampuan untuk membimbing dan mengarahkan diri dan masyarakat untuk melaksanakan tugas-tugas dan perannya sebagai khalifah fil ardh.

b. Hakikat manusia sebagai integrasi yang utuh antara dimensi jasmani dan rohani, maka tujuan pendidikan Islam adalah mengembangkan potensi jismiyah manusia secara maksimal agar mereka berkemampuan untuk mengembangkan dan terampil dalam melakukan tugas-tugas kehidupan fisiknya. Selain itu, pendidikan juga bertujuan untuk mengembangkan potensi ruhiyah manusia agar mereka memiliki kemampuan yang cerdas secara intelektual ('aqliyah), terpuji secara moralemosional (qalbiyah) dan tercerahkan secara spiritual (nafsiyah).

\section{Kurikulum Pendidikan Islam}

Kurikulum pendidikan berbasis pluralisme yang disusun Maarif Institute, telah menyemaikan benih-benih pluralisme dalam pendidikan. Karena kurikulum dijadikan sebagai manhaj dan seperangkat perencanaan dalam mewujudkan tujuannya, maka untuk mencapai tujuan memahamkan nilai-nilai pluralisme kepada manusia, Maarif Institute menyusun kurikulum yang terkait hubungan antara agama satu dengan agama lainnya agar terjadi keharmonisan dan toleransi. (Lestari, 2012)

Maarif Institute juga merujuk kepada ayat-ayat Al-Qur'an dalam menyusun kurikulumnya, Namun ayat-ayat yang digunakan adalah ayat-ayat yang (menurut mereka) mendukung pluralisme. Sedangkan dalam menyusun kurikulum, selain dari AlQur'an juga harus merujuk kepada Hadist Rasulullah SAW. termasuk dalam pengembangan kurikulumnya disusun dan dirumuskan berlandaskan Al-Qur'an dan AsSunah sebagai sumber utamanya. Meskipun Al-Qur'an dan Sunah adalah bukan "kitab pengembangan kurikulum”, melainkan “kitab hidayah”, akan tetapi Al-Qur'an dan Hadist memberikan indikasi-indikasi umum (ijmaliyah) dalam pengembangan kurikulum agar terbentuk karakteristik pendidikan yang rabbaniyyah.

Jika kita meneliti pada tabel Standar Kompetensi dan Kompetensi Dasar yang digunakan Maarif Institute, maka akan terlihat kesalahan dan keteledorannya dalam menyusun kurikulum. Penulis berasumsi bahwa terjadi ketidaksesuaian pada Standar Kompetensinya, tepatnya pada BAB 12 . Berikut potongan tabelnya: 
Studi Kritis Konsep Pendidikan Berbasis Pluralisme Di Maarif Institute

\begin{tabular}{|c|c|c|c|}
\hline Judul Bab & $\begin{array}{c}\text { Standar } \\
\text { Kompetensi (SK) }\end{array}$ & $\begin{array}{l}\text { Kompetensi Dasar } \\
\text { (KD) }\end{array}$ & Kelas \\
\hline $\begin{array}{l}\text { BAB } 12 \\
\text { Menghargai Karya Dan } \\
\text { Budaya Bangsa Lain }\end{array}$ & $\begin{array}{l}\text { Akhlak } \\
\text { Meningkatkan } \\
\text { Keimanan di hari } \\
\text { akhir }\end{array}$ & $\begin{array}{l}\text { Membiasakan } \\
\text { perilaku } \\
\text { menghargai karya } \\
\text { orang lain dalam } \\
\text { kehidupan sehari- } \\
\text { hari }\end{array}$ & $\begin{array}{l}\text { Kelas XII, } \\
\text { Semester } 1\end{array}$ \\
\hline
\end{tabular}

Ketidaksesuaian yang penulis maksud adalah adanya pembahasan mengenai “Meningkatkan Keimanan di Hari Akhir" pada BAB yang membahas seputar akhlak. Ini adalah hal yang sama sekali tidak sesuai, karena berbicara keimanan seseorang adalah ranah akidah.

Pandangan Al-Ghazali terhadap kurikulum dapat dipahami dari pandangan mengenai Ilmu Pengetahuan. (Ramayulis, 2005) Kurikulum pendidikan yang disusun alGhazali sesuai pandangannya mengenai tujuan pendidikan yakni mendekatkan diri kepada Allah yang merupakan tolak ukur manusia. Untuk menuju ke sana diperlukan ilmu pengetahuan. Mengurai kurikulum pendidikan menurut al-ghazali, ada dua hal yang menarik bagi kita. Pertama, pengklasifikasian terhadap ilmu pengetahuan yang sangat terperinci dalam segala aspek yang terkait dengannya. Kedua, pemikiran tentang manusia dengan segala potensi yang dibawanya sejak lahir.

Hal paling penting dan harus ada dalam kurikulum setiap pendidikan adalah adanya materi tentang akidah dan tauhid. Dapat diuraikan tentang Pendidikan Aqidah, Pendidikan Tauhid, dan Pendidikan Iman. Dengan adanya bekal materi tersebut kepada manusia (peserta didik) maka akan membuka pengetahuan mereka untuk selalu memperkuat keimanan dan rasa penghambaan dirinya kepada Allah SWT. Dengan demikian akan dapat pula menyelamatkan pendidikan dari virus-virus pluralisme.

Menurut Ibnu Jama, kurikulum yang harus diterapkan dalam pendidikan harus bersifat keagamaan. Menurut beliau pelajaran yang harus diutamakan adalah Al-Quran, Tafsir, Hadits, Ulum Al-Hadits, Ushul Al-Fiqh, Nahwu dan Shorof. Setelah itu, kurikulum tersebut dilanjutkan dengan pengembangan-pengembangan bidang lain dengan tetap mengacu kepada kurikulum diatas. Seperti ilmu-ilmu tentang perbedaan madzhabdalam Fikih-, ilmu aqliyat (kalam) dan al-Sam'iyat (Tasawuf) dan lainnya. Ibn Jama tidak berbicara tentang klasifikasi ilmu kepada Syar'i atau Ghairu Syar'i maupun yang Fardlu 'Ain atau Fardlu Kifayah, namun dari pemaparan di atas dapat kita pahami bahwa ilmu yang dimaksudkan adalah ilmu agama. 


\section{Kritikan Terhadap Nilai-nilai Pluralisme Maarif Institute}

Tiga term yang dijadikan pintu penyebaran nilai-nilai pluralisme oleh Maarif Institute, tanpa mengindahkan nilai-nilai akidah sebagai muslim. Hal tersebut perlu diklarifikasi dan dikritisi. Di antaranya:

\section{Nilai-nilai Toleransi}

Maarif Institute mengajarkan bagaimana masyarakat (peserta didik) paham akan nilai-nilai toleransi dan implementasinya, hak beragama dan menghargai agama lain, hak dalam menjalankan praktik keagamaan, dalam ranah dakwah yaitu mengajak tanpa memaksa dan berlaku adil terhadap perbedaan. Di antara contoh ajaran toleransi yang dikembangkan oleh Maarif Institute adalah "buka bersama di warung nasi peduli kasih" dan "lebaran dan halal bi halal: oase kebersamaan."

Dian menuliskan bahwa: "toleransi merupakan modal utama untuk menciptakan kerukunan dan keadilan dalam kehidupan di dunia ini. Kita semua memahami bahwa realitas kehidupan sangat beragam, karakter toleran adalah kesediaan untuk menerima dan menghargai realitas yang majemuk."

Sedangkan menurut Adnin Armas, toleransi beragama memang harus dilakukan sesama warga yang beragama. Asal tidak menyinggung ke dalam rnasalah akidah. Jika sudah merasuki ke ranah akidah dan keyakinan, itu bukan lagi namanya toleransi, tetapi pluralisme agama. Adnin Armas mengatakan:

"Toleransi, kekerasan dan lain sebagainya itu sebenarnya sesuatu yang baik dan bagus, Cuma masalahnya ketika memaknai toleransi tersebut seperti apa. Apakah umat Islam tidak toleran karena menjaga akidah? apakah dengan membiarkan kesesatan disebut tidak toleran? apakah umat Islam harus ikut merayakan natal bersama biar disebut toleran sementara kalau tidak merayakan natal disebut tidak toleran? dengan kosakata kafir itu menjadikan tidak toleran? Nah, sebenarnya toleransi itu tidak seperti itu. Justru toleransi itu harus menegaskan perbedaan bukan meleburkan perbedaan, artinya mempertegas identitas sebagai umat muslim."

"Toleransi itu tidak boleh sampai meleburkan identitas. Identitas keislaman harus dihilangkan demi sikap toleransi yang seharusnya tidak disyariatkan dalam Islam, justru hal itu menjadi tidak toleran bagi Islam. Jadi, masalahnya terletak pada memaknai toleransi tersebut, siapa yang memberikan makna toleransi tersebut, makna toleransi oleh Maarif Institute itu adalah makna yang salah. Karena menghilangkan identitas umat Islam bukanlah sebuah toleransi, justru tidak toleran terhadap umat Islam, karena bagian daripada keyakinan beragama."

Kaitannya dengan dunia pendidikan, menurut Adnin Armas toleransi jangan sampai menghilangkan identitas. Pendidikan Islam harus tetap pada identitasnya. Justru 
identitas-identitas tersebut harus diperjelas kemudian makna toleransi itu harus dibongkar dan direkonstruksi karena terjadi pemaknaan yang salah sudah beredar.

\section{Nilai-nilai Anti Kekerasan}

Kekerasan tidak akan terjadi jika masyarakat berjalan pada alurnya masing-masing dan tidak saling menyinggung satu dengan yang lainnya. Dalam hal anti kekerasan ini, adalah permasalahan akidah umat Islam. Umat Islam akan marah apabila Allah sebagai Sang Pencipta disekutukan, apalagi mengatakan ada agama, Tuhan dan nabi baru.

Anti kekerasan yang dibiasakan Maarif Institute adalah mengajarkan nilai-nilai anti kekerasan tersebut serta implementasinya. yaitu demokrasi dalam masyarakat, memahami dan mengelola konflik, belajar mengakui kesalahan dan menerapkan sikap memberi maaf, peserta didik secara aktif mencegah dirinya dan orang yang melakukan upaya provokasi, menyebar kebencian, dan aksi kekerasan terhadap pihak lain, baik kekerasan fisik maupun kekerasan verbal.

Sesuai yang diungkapkan oleh Fajar Riza UI Haq dalam membela kaum minoritas:

"Berlarutnya penyelesaian berbagai kasus-kasus seperti kasus lemahnya perlindungan terhadap Ahmadiyah dan penyelesaian kasus korupsi kakap telah menimbulkan defisit kepercayaan publik terhadap pemerintah saat ini. Dalam hal perlindungan terhadap kelompok minoritas justru semakin meningkat pada tahun 2010 . Pembiaran aksi-aksi intoleransi tersebut merupakan sebuah anomali dalam proses demokrasi. (Haq, 2011) "Masa depan demokrasi Indonesia yang masih belia terancam jika aparat negara dan kelompok berbasis keagamaan tidak meredam kekerasan yang terjadi”. (Haq, n.d.)

Anti kekerasan merupakan nilai kebaikan yang bersifat universal. Artinya semua ajaran agama mengajarkan kepada pemeluknya untuk tidak melakukan tindakan anti kekerasan. Harus saling menjaga kesejahteraan, keamanan, ketenangan hidup bermasyarakat, ataupun antar individu.

Hal ini akan menjadi masalah jika dilakukan dengan membelakangi nilai-nilai akidah agama Islam. Jika yang diperlakukan dengan kekerasan itu adalah mereka yang menyinggung bahkan merusak akidah umat Islam, maka sudah seharusnya untuk mengambil tindak pencegahan. Jika dengan pencegahan tidak berhasil, maka perlu ditindak dengan kekerasan.

Melihat permasalahan di atas bukanlah berdasarkan keadaan masyarakat, tetapi bersinggungan dengan akidah umat Islam dan bagaimana menjaga akidah umat Islam. Jika dianalogikan bahwa tidak akan ada orang yang bersedia jika di dalam rumahnya dibangun rumah baru (membangun rumah baru di dalam rumah). Selain menimbulkan hal yang janggal dan tidak diterima, juga merupakan hal yang mustahil untuk dilakukan. 


\section{Inklusifitas/Keterbukaan}

Dian menuliskan dalam bukunya bahwa:

"Sebelum Islam masuk ke Indonesia, Indonesia sudah terbentuk dan berkembang berbagai budaya, kepercayaan dan agama. Kemudian Islam datang sebagai agama baru yang berkembang di lingkaran sejarah budaya nusantara. Oleh karenanya kehadiran Islam adalah bagian dari perjalanan panjang sejarah bangsa ini, Islam telah memberikan warna kebudayaan bagi sejarah bangsa ini. Maka Islam tidak seharusnya dipisahkan atau dipertentangkan dengan budaya nusantara”. (Lestari, 2012)

Dari ungkapan di atas jelas terlihat bahwa, Islam harus mengikuti atau menyesuaikan dengan budaya dan kebiasaan yang sudah ada sebelum Islam. ini merupakan sebuah pemikiran yang fatal dan salah. Karena sudah jauh lebih dahulu ada dan telah mengatur semuanya. Jadi sangat tidak sesuai sekali jika Islam yang harus menyesuaikan dengan kebudayaan nusantara.

Mengakui adanya nilai inklusifitas ini bukan berarti agama Islam harus menurut dengan kebudayaan-kebudayaan yang ada sekarang ini atau konsep agama harus menyesuaikan dengan kebudayaan yang berkembang.

Penulis ingin memberikan sebuah analogi dalam memahami korelasi antara budaya dan Islam pada zaman sekarang ini. Bahwa, kita ibaratkan Islam adalah kepala sedangkan kebudayaan di nusantara ibarat peci atau topi. Jika ukuran peci yang digunakan sudah tidak sesuai lagi dengan ukuran kepala, maka ukuran peci yang harus diganti, yang tadinya ukuran tujuh maka diganti ukuran delapan, sembilan atau ukuran lainnya (yang sesuai). Bukannya postur tengkorak kepala yang dibongkar dan diperkecil. Jika ini dilakukan maka akan berakibat fatal bahkan kematian bagi para pengguna peci tersebut.

Jika analogi ini ditarik dalam mengkaji keterbukaan dengan Islam, maka hasil sikap keterbukaan itulah (seperti: inklusif, kebudayaan, menghargai perbedaan dll.) yang harus menyesuaikan dengan konsep Islam.

\section{KESIMPULAN}

Konsep pendidikan berbasis pluralisme di Maarif Institute adalah sebuah konsep pendidikan yang berdasarkan kepada nilai-nilai toleransi, inklusifitas dan mengembangkan nilai anti kekerasan atas nama agama dan golongan. Toleransi yang dikembangkan baik dalam hubungan sosial, atas nama agama, pikiran dan menghargai praktik ibadah agama. Ayat-ayat Al-Qur'an yang dijadikan dalih oleh Maarif Institute dalam mengonsep pendidikan berbasis pluralisme di antaranya: QS Al-Hujurat: 12-13, Al-Maidah: 8, Al-Kafiri: 6 dan beberapa ayat Al-Qur'an lainnya. Tujuan konsep 
pendidikan berbasis pluralisme di Maarif Institute adalah untuk melahirkan peserta didik yang memahami dan mampu mengembangkan nilai toleransi, inklusifitas dan anti kekerasan dalam pergaulan. Adapun kurikulum yang digunakan adalah kurikulum berbasis nilai-nilai pluralisme. Yang dibentuk dalam tiga term yaitu mengenai nilai-nilai toleransi, nilai-nilai inklusifitas dan pengembangan nilai-nilai anti kekerasan.

Dalam perspektif pendidikan Islam, konsep pendidikan berbasis pluralisme oleh Maarif Institute sangat berbahaya jika diaplikasi dalam kurikulum pendidikan. Konsep pendidikan tersebut mengaburkan pemahaman dan keyakinan-keyakinan peserta didik terhadap Allah SWT, dan terhadap konsep-konsep Islam yang sudah disusun rapi berabad-abad lamanya. Pendidikan Islam berbasis pluralisme oleh Maarif Institute terbukti berusaha mengikis keyakinan beragama umat Islam yang benar dan bersumber kepada Al-Qur'an dan Sunah. Ketika proses merubah keyakinan agama umat Islam menjadi pluralis, akan memudahkan kalangan sekuler-liberal untuk melanjutkan visi penjajahan peradabannya kepada lokasi-lokasi Muslim lainnya. Inilah hal besar yang harus diwaspadai dari konsep pendidikan berbasis pluralisme. Dan ini harus ditanggulangi secara serius oleh para pakar dan tokoh-tokoh pendidikan Islam.

\section{DAFTAR PUSTAKA}

An-Nahlawi, A. (1996). Ushul At-Tarbiyah Al-Islamiyah wa Asalibuha, terj. Herry Noer Ali, Prinsip-prinsip dan Metode Pendidikan Islam. Bandung: CV. Diponegoro.

Armas, A. (2003). Pengaruh Kristen Orientalis terhadap Islam Liberal. Jakarta: Gema Insani Press.

Barton, G. (1999). Gagasan Islam Liberal di Indonesia: Pemikiran Neo-Modernisme Nurkholis Madjid, Djohan Efendi, Ahmad Wahib, dan Abdurrahman Wahid. Jakarta: Pustaka Antara.

Dzulhadi, Q. N. (2013). Membongkar Kedok Liberalisme di Indonesia; Studi Kritis Pemikiran Sekularisme, Pluralisme, dan Liberalisme. Jakarta: Cakrawala Publising.

Haq, F. R. U. (2011). Demokrasi Kaum Kriminal. Dalam Jurnal Maarif, 6(1).

Haq, F. R. U. (n.d.). Kekerasan Meningkat, Demokrasi Terancam. Retrieved from http://nasional.kompas.com/read/2010/12/16/04425515/

Husaini, A. (2005). Wajah Peradaban Barat. Jakarta: Gema Insani.

Husaini, A. (n.d.). Islamic Worldview. Bogor: Universitas Ibn Khaldun Bogor.

Jurnal Maarif Institute, Arus Pemikiran Islam dan Sosial (Vol. 7). (2012). Jakarta: Maarif Institute.

Langulung, H. (1989). Manusia Dan Pendidikan. Jakarta: Pustaka Al Husna.

Lestari, D. (2012). Pendidikan Karakter: Mengarusutamakan Nilai-nilai Toleransi Anti Kekerasan dan Inklusif. Jakarta: Maarif Institute.

Maarif, A. S. (2004). Mencari Autentisitas Dalam Kegalauan. Jakarta.

Mahfud, C. (2010). Pendidikan Multikultural. Yogyakarta: Pustaka Pelajar.

Mastuhu. (1999). Memberdayakan Sistem Pendidikan Islam. Jakarta. 
Miskawaih, I. (1329). Tahzib al-Akhlaq wa Tathhir al-A'raq. Mesin: al-Husaini.

Naim, N., \& Sauqi, A. (2010). Pendidikan Multikultural: Konsep dan Aplikasi. Yogyakarta: Ar Ruzz Media.

Nata, A. (2005). Pendidikan Islam di Era Globa (Pendidikan Multikultural, Pendidikan Multi Iman, Pendidikan Agama, Moral, dan Etika). Jakarta: UIN Press.

Ramayulis. (2005). Ensiklopedi Toko Pendidikan Islam (Mengenal Tokoh Pendidikan di Dunia Islam dan. Indonesia, Ciputat: Quantum Teaching.

Rasyidin, A. (2008). Falsafah Pendidikan Islam: Membangun Kerangka Ontologi, Epistimologi, dan Aksiologi Praktik Pendidikan. Bandung: Citapustaka.

Shihab, M. Q. (2004). Tafsir Al-Misbah: Pesan, Kesan dan Keserasian Al-Qur'an, Volume 1. Jakarta: Lentera Hati.

Syafin, N. (2007). Kritik Terhadap Paham Liberalisasi Syariat Islam. Jakarta: Dewan Dakwah Islam Indonesia. 